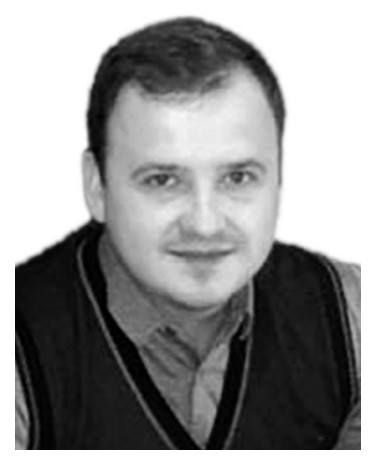

\title{
СВІТОГЛЯДНІ ВИТОКИ ТА ОНТОЛОГІЧНІ ОСОБЛИВОСТІ ДАВНЬОГРЕЦЬКОӤ ФІЛОСОФІї ПРАВА ДОСОКРАТИЧНОГО ПЕРІОДУ
}

\author{
ВАНДЖУРАК Роман Васильович - аспірант кафедри філософії права та \\ юридичної логіки Національної академії внутрішніх справ \\ DOI:10.32782/NP.2019.4.26 \\ УДК 340.12
}

\begin{abstract}
У змісті статті на основі онтогносеологічного аналізу викладене авторсъке бачення ролі та впливу давньогрецької болособбї права досократичного періоду на становлення та еволюиію бундаментальних понять притаманних фоілособії права сучасності. Автором розкриваються основні онтологічні позищиі давньогрецьких мислителів, які є представниками досократичного періоду давнъогрецького білософсько-правового сприйняття оточуючоі реальності. Вказується на різноманітність поглядів тогочасних мислителів на такі сочіально-значимі категорї, як держава, право, закон, система управління тощо. Зазначається, що тогочасні мислителі прагнули встановити першопричину усъого існуючого у Всесвіті. У даному прагненні вони звертали свою увагу на різноманітні предмети $i$ явища, які були осяжними для людського сприйняття та знаходилися поза межами людсъкого «Я». Іншими словами пошук першопричини у досократиків знаходився у площині, яка знаходилася поза самою сутністю індивіда. У даному разі людина виступала виключно у ролі суб'єкта наукового пошуку, а сам вектор пізнання був спрямований від сочіального індивіда - на зовні.

Ключові слова: давньогрецька філософія права, до сократичний період, вихідний елемент, право, закон, держава, система управління.
\end{abstract}

Постановка проблеми та актуальність теми

Намагаючись пояснити першопричину усього існуючого, а також взаємозв'язок, який існує між об’єктами «сущого», тогочасні мислителі не могли залишити поза увагою і такі соціальні феномени, як право, держава, закон, система управління тощо. Адже саме за допомогою вказаних феноменів стає можливою побудова певного механізму соціального регулювання. I хоча у кожного представника досократичного періоду давньогрецької філософії було власне бачення такого механізму, вони, з рештою, приходили до хоча й оригінальних за змістом, але однакових за своєю суттю висновків з приводу того, що і зазначені феномени повинні вибудовуватися на основі природних законів, чим забезпечується певна рівновага у стосунках між окремими соціальними одиницями. Саме тому наукова спадщина представників досократичного періоду давньогрецької філософії $є$ досить цікавою та потребує ретельного аналітичного дослідження 3 метою застосування притаманних їй наукових принципів в умовах сьогодення, адже проблематика визначення феноменології права, держави, закону, системи управління тощо, і на сьогоднішній день залишається надзвичайно актуальною і ретроспективний аналіз еволюції даних понять надасть змогу проведення досить ретельного дослідження вказаних феноменів у проекції проблематики сьогодення.

Стан наукової розробки теми

Проблематикою давньогрецької філософії права досократичного періоду займалися такі вітчизняні та зарубіжні дослідники, як М.В.Костицький, В.М.Вовк, С.Г.Меленко, С.Я.Аур'є, А.О.Маковельський, Б.Рассел, 
В.С.Нерсесянц та ін. Але слід вказати на те, що у змістовому наповненні існуючих наукових праць проблематика саме онтологічного аналізу філософсько-правових поглядів представників досократичного періоду давньогрецької філософії не виступає у ролі основного предмету наукового пошуку. Ретельному аналізові піддаються лише праці окремих мислителів вказаного періоду, або ж даються лише узагальнюючі оцінки притаманних їм філософсько-правовим поглядам. Саме тому дана стаття покликана, на думку автора, частково звузити зазначену прогалину.

Метою статті є комплексне онтологічне дослідження наукової спадщини представників давньогрецької філософсько-правової думки досократичного періоду.

\section{Виклад основного матеріалу}

Відлікові «рамки» темпорального періоду за якого у давньогрецькому соціальному середовищі поряд зі звичними, повсякденними роздумами побутового характеру з'являються уявлення філософсько-світоглядного змісту, на превеликий жаль, можливо встановити лише з надзвичайно великою похибкою вірогідності. В умовах сьогодення дане завдання можливо виконати лише на основі результатів глибокого гносеологічного аналізу аксіологічно-змістового наповнення тогочасних пам'яток текстуальної фіксації інформації та фольклору, які дійшли до наших часів, наклавши їх у темпоральному вимірі на роки життя та творчості авторів давньогрецьких фоліантів філософсько-світоглядного характеру. У свою чергу зазначена методологія не вирізняється вкрай необхідною під час наукового пошуку точністю та об'єктивністю, а тому носить лише відносний характер, що, без сумніву, відображається також, певним чином, і на змістовій частині інших сучасних наукових розвідок, які присвячені згаданій проблематиці. Втім ми також не можемо безапеляційно стверджувати, що перші давньогрецькі письмові пам'ятки, які дійшли до наших часів та у змісті яких відображено роздуми тогочасних мислителів 3 приводу будови Космосу, створення Всесвіту та місця і призначення людини у ньому, є саме тим, первинним, вихідним варіантом зазначених суджень, зафіксованих за допомогою методології, яка є зрозумілою та доступною для використання на сьогодні. Зауважимо, що саме первинні варіанти вказаних роздумів давньогрецьких мислителів існували в усній формі, або ж навіть піддавалися і письмовій фіксації, але $з$ великою часткою вірогідності фактично не змогли дійти до наших днів - або ж безслідно зникли, або ж ще очікують на власне відкриття дослідницькою спільнотою. Саме тому, на нашу думку, слід змиритися з тим фактом, що на сьогодні не встановлено єдиного більш-менш точного часового періоду, 3 якого бере власний початок феномен давньогрецької філософії.

Натомість переважна більшість науковців, які проводять власні наукові розвідки у межах зазначеної тематики, демонструють здебільшого одностайність щодо причин прояву та розвитку феномену філософського аналізу на теренах Давньої Греції. Зокрема досить поширеною та логічно обгрунтованою $є$ гіпотеза з приводу того, що процесам зародження, становлення та розвитку давньогрецької філософії сприяло географічне положення, в межах якого існував тогочасний грецький соціум. А також особливості суспільного та політичного устрою давньогрецьких міст-держав (полісів), рід занять населення, рівень розвитку культури, релігійних вірувань, уявлень та переконань тощо. Приміром У. К. Ч. Гатрі у своїй багатотомній праці «Історія грецької філософії [2, с.108-110], яка вирізняється грунтовністю та глибиною проведеного наукового дослідження, сформулював онтологічне запитання з приводу того, що ж відіграло роль первинного імпульсу «зачаття» давньогрецької філософії, і надав на нього цілком логічну відповідь - вона бере власний початок з тих часів, коли в давніх греків почало формуватися глибоке переконання з приводу того, що видимий хаос оточуючих процесів повинен нести у власній основі певний порядок, і що цей стан речей є породженням сил неземного походження. На ранніх етапах розвитку та становлення давньогрецьких філософських уявлень вказаний стан речей давньогрецькими мислителями пояснювався завдяки використанню міфологічно-гносеологічного інструментарію та притаманної йому методології, які у своїй уяві наділяли окремих уявних 


\section{Філософія та психологія права}

персонажів божественними властивостями та владою над тими чи іншими надзвичайними силами природи, створивши таким чином певний пантеон богів, який вирізнявся чіткою ієрархією, та на чолі якого знаходився головний бог, який власне наділявся предикатами творця та виступав у ролі першооснови усього сущого (видимого та невидимого). Та, вочевидь, не всіх членів давньогрецького соціуму повністю задовольняло таке пояснення й тому окремі його представники починають власний онтологічний пошук відповіді на ці запитання, завдяки використанню методології спостереження та раціонального пояснення того чи іншого явища чи уявлення, не вдаючись до сліпого сприйняття міфологічних постулатів. Це «відхилення» від вектору міфологічного інструментарію і $є$, на думку У. К. Ч. Гатрі, фактором чи моментом саме зародження давньогрецької філософії.

Варто наголосити на тому, що на початковому, вихідному етапі інтерес давньогрецьких філософів тяжів, здебільшого, до проблем визначення першооснов буття як такого, будови Космосу й пояснення аксіологічно-онтологічної складової всього сущого, а тому цей період прийнято називати - космологізмом ранньої давньогрецької філософії. Не залишили греки поза власною увагою й право, а відтак можна з упевненістю стверджувати, що одночасно із зародженням, становленням та розвитком давньогрецької філософії відбувалися аналогічні процеси й у царині філософії права.

У науковому світі першим давньогрецьким філософом прийнято вважати Фалеса Мілетського, засновника Мілетської школи (від назви міста Мілет, теперішня західна частина Туреччини), від народження якого фактично бере власний початок уся європейська наука. У 585 році до н.е. Фалес передбачив точну дату й час затемнення сонця й саме цей рік у середовищі науковців вважається роком виникнення давньогрецької філософії. Фалес першим серед тогочасних мислителів ризикнув пояснити проблематику створення Всесвіту фактично не покладаючись на міфологію, а послуговуючись науковим інструментарієм, який за власною природою $є$ раціональним. На переконання Фалеса основою усього сущого та вихідним першоджерелом є вода, яка у притаманних їй трьох станах породжує все суще шляхом змінюваності цих станів у різних послідовностях. Щодо проблематики права, то на думку С. Г. Меленка, на зорі зародження та розвитку філософії, Фалесом були сформульовані ідеї політичного та державницького характеру, які вже на той час відіграли неабияку роль у розвитку еллінського суспільства [10, с.30]. Фалесу приписують максиму: «Не роби того, що ти засуджуєш в інших» $[15$, с.3]. Ця максима на своєму історичному шляху відіграла роль основи «золотого правила» моральності й знайшла власне відображення в релігійних вченнях, філософських трактатах й правових системах різних держав, у тому числі й сучасних [4, с.122].

Наступним представником Мілетської школи був учень Фалеса - Анаксімандр, який всупереч своєму вчителю вважав першоосновою не емпіричний елемент, а уявний, абстрактний - апейрон: невизначену субстанцію, що не набула жодних емпіричних якостей, тобто ту, що вміщає в себе все й одразу, яку неможливо відчути, вона вічна й знаходиться в постійному русі [11, с.18-22]. Основною ідеєю мислителя $є$ рівновага, як у проекції Всесвіту так й в державі, праві й суспільстві, які на думку мислителя є невід'ємною частиною Всесвіту [1, с.23]. Переносячи ідеї Анаксімандра на сьогочасне суспільство, можна для прикладу вказати на таке соціальне явище, як злочин, який є безумовним порушенням рівноваги, оскільки вбивство чи нанесення фізичних ушкоджень порушує наперед визначений порядок та провокує виникнення дисбалансу в суспільстві, усунення якого стає можливим лише завдяки втручанню до вказаної сфери суспільних відносин спеціалізованих державних інституцій, які, у свою чергу, завдяки застосуванню примусу в інтересах суспільства відновлюють втрачену гармонію.

Неможливо недооцінити значення світоглядних ідей Анаксімандра для процесів широкого дослідження різноманітних аспектів онтологічного та аксіологічного характеру, які притаманні філософії права, зокрема не лише у їі теоретичному вимірі, але й у практичному контексті, адже ідеї мислителя зберегли власну актуальні й до нині; вони фактично $є$ ідейним підгрунтям створення та 
розбудови онтологічно-необхідних державних інституцій різноманітних сучасних державних утворень.

Третім, із відомих нам, представників Мілетської філософської школи виступав учень Анаксімандра - Анаксімен, який вважав саме повітря першосоновою всього сущого, яке у своїх різних притаманних йому станах може перетворюватися на вогонь, воду, каміння, гори тощо. Анаксімен фактично виступав у ролі першого мислителя, який не лише звернув досить пильну гносеологічну увагу на таку філософську категорію, як душа, але й намагався завдяки притаманним їй якостям пізнати основи світобудови. На жаль Анаксімена не цікавили питання державно-правового характеру, але його світоглядні ідеї, які вирізнялися оригінальністю, відіграли досить значну роль у процесах синтезу світоглядних першооснов у сфері наукових досліджень, як природничого так і не природничого характеру.

Досить вагомого значення у межах парадигми гносеологічного пізнання філософсько-правової спадщини досократичного періоду набувають світоглядні ідеї такого давньогрецького мислителя, як Піфагор, а також його послідовників - представників піфагорійської філософської школи. Про Піфагора нам майже нічого не відомо хоча про його особистість написано сотні книг, різночасових наукових трактатів та статей. Нам відомо, що Піфагор вперше ввів до сфери загального вжитку поняття «філософія» (любов до мудрості) й прагнув щоб його називали філософом а не мудрецем, пояснюючи це тим, що мудрим може бути лише Бог, а людина здатна лишень любити мудрість, тобто бути філософом. На відміну від «мілетців», Піфагор вірив у існування Бога, проте піфагорійський бог - це «число чисел, єдиний, хто містить у собі все....» [14, с.8] Загалом, «фарватером» філософії піфагорійців було їхнє вчення про числа, де кожне явище (фізичне й уявне) мало своє унікальне число. 3 чисел піфагорійці вивели й поняття «рівність», яке можливе при існуванні права, як рівної міри нормування нерівних відносин. Справедливість на думку піфагорійців виражена у змісті числа «чотири» (множення цифри два на саму себе), де сутність справедливості проявляється у «від- дачі рівного за рівне». Разом із тим, рівність у піфагорійців не виокремлювалася сталістю, а саме - не набувала значення, яке би було єдиним для всіх, а, у свою чергу, корегувалася у залежності від змісту кожного окремо узятого випадку [12, с.25-28].

3 особливою пошаною піфагорійці ставилися до такої філософсько-аксіологічної категорії, як закон. Законослухняність вони відносили до сфери високих чеснот, а самі закони вважали чи не найбільшою цінністю. Безпосередній прояв зла піфагорійці вбачали у безвладді (анархії), будучи переконаними, що людина за своєю природою не може обійтися без керівника, спрямовуючої сили, а також - належного виховання.

Ідеальною формою державного управління піфагорійці вважали аристократію, будучи переконаними, що враховувати зміст думок будь-кого є нерозумним, а тим більше, якщо це думки натовпу, навіть якщо вони стосуються питань управління державою. Головними ознаками ідеального управлінця, на їнє глибоке переконання, є освіченість, а ця риса, у свою чергу, є притаманною майже виключно представникам аристократії.

Загалом філософське вчення Піфагора та його послідовників, а особливо притаманні їм політико-правові погляди спричинили неабиякий вплив на подальший еволюційний поступ давньогрецької філософії права зокрема та на процеси формування державноправових механізмів та інституцій на теренах Европи загалом. Сформульовані ними концептуальні ідеї можна означити під час проведення детального логіко-гносеологічного аналізу змісту сентенцій, викладених Сократом у власному філософсько-світоглядному вченні, змісті творів, що належать перу Платона, а також у наукових викладах авторів більш пізніх часових періодів. Досить часто різноманітні світоглядні ідеологеми сформульовані представниками піфагорійської філософської школи знаходять власне відображення в різноманітних сферах буття сучасного суспільства, що зайвий раз свідчить про притаманні їм аксіологічну та онтологічну складові.

Не менш значимою фігурою у сфері давньогрецької філософії є постать Геракліта. Його вважають першим діалектиком і саме 


\section{Філософія та психологія права}

йому приписують введення до парадигми філософського пізнання світу такого поняття як «логос», який у розумінні мислителя був основоположним законом буття. Все у світі, згідно уявлень Геракліта, перебуває у постійному русі, зміні, боротьбі й оновленні. На нашу думку зі змісту зазначеного й випливає належний філософові найвідоміший вислів: «Не можна двічі увійти в одну і ту ж саму ріку» [3, c.113]. У цьому вічному потоці змін все складається 3 протилежностей, основою впорядкованості між якими є вогонь, у якості загального еквівалента взаємоперехідних протилежних явищ, на який обмінюється все суще.

Стосовно політико-правових поглядів Геракліта, слід зауважити, що під час дослідження творчого спадку мислителя відкривається можливість ї аналізу в контексті світоглядної сфери світосприйняття філософа у цілому, оскільки жодних наукових пам'яток письмового характеру, які б присвячувалися згаданій тематиці, Гераклітом залишено не було. Разом із тим, на глибоке переконання мислителя, люди не є рівноцінними один одному, так як саме по собі мислення - це велике благо, а більшість людей - є нерозумними створіннями. Звідси й бере власний початок критичне ставлення Геракліта до демократії, як форми правління, яку він вважав - «правлінням нерозумних». На його глибоке переконання державою мають керувати «кращі», тобто еліта. Для Геракліта рішення одного «кращого» індивіда, зокрема, є більш аксіологічно-наповненим феноменом аніж думка демосу загалом. «Один для мене - десять тисяч, якщо він найкращий» - зазначав мислитель [13, с.697].

Геракліт був яскравим прибічником писаного (позитивного) права, тобто, на думку філософа, закони створюються «кращими», i за них, згідно відомого вислову мислителя, народ повинен боротися, як за стіни фортеці [3, с.113].

3 аксіологічного змісту вчення Геракліта бере свій початок такий філософсько-світоглядний напрям наукового пізнання, як діалектика, яка тисячоліття по тому була розвинута Ф. Гегелем, а згодом і К. Марксом. Та і загалом - завдяки глибокозмістовним поглядам мислителя в юридичній науці було сформовано доктрину позитивного права.
Не менш цікавою для дослідження $є$ й Елейська філософська школа (м. Елея, на півдні Італії), засновником якої вважається Ксенофан, щоправда слава цієї школи тісно пов'язується з іменами таких мислителів як Парменід та Зенон.

Прихильники даного філософського напрямку пізнання виступали у ролі основоположників онтології - вчення про буття. Унікальністю притаманних їм світоглядних поглядів є те, що вони вперше заявили про існування двох, часто протилежних одна одній форм людського пізнання: чуттєвого й розумового, надаючи пріоритетності саме останньому.

На думку Парменіда буттям 6 все, що можна пізнати розумом, натомість саме буття як феномен, за своєю природою є недоступним відчуттям, адже відчуття, у свою чергу, є категоріями обмеженими та ненадійними. Прихильником цієї ж думки виступав і Зенон, який за допомогою власних апорій доводив неістинність видимого і чуттєвого, тим самим стверджуючи, що істинна картина світу може бути осягнута лише за допомогою мислення, тобто завдяки силі думки.

На даний час науковому співтовариству ще не відомі погляди елеатів, які вони висловлювали на адресу таких інституцій, як держава, форми правління та права як такого, але, зокрема, онтологічні ідеї сформульованого ними вчення вирізняються слушністю і в умовах сьогодення, в контексті такої важливої сфери людського буття, як правозастосування. Дана концепція і в наш час знаходить власне відображення у змісті процесуальних актів різних країн світу, що слугує доказом неприпустимості реалізації процесів законотворення та правозастосування під будь-яким впливом почуттів особистісного характеру.

Надзвичайно жвавий інтерес викликають і світоглядні уявлення представників Іонійської школи натурфілософії (від місцевості Іонія, на даний час - західна частина Туреччини, до якої, до речі, входило й місто Мілет), серед яких можна виокремити такі відомі постаті представників давньогрецької філософії, як Емпедокл, Анаксагор, Архелай та Діоген Аполонійський. Зокрема Емпедокл, учень Піфагора, був прихильником мілетської філософської школи, втім не завжди погоджувався 
з ідеями, сформульованими ії представниками. Зокрема мислитель критично ставився до вчення стосовно єдиного першоелемента, будучи переконаним, що першоосновою космосу є всі чотири елементи природних стихій, а саме - вогонь, земля, повітря й вода. Їх поєднання та диференціація, на думку філософа, створює і руйнує фактори які виступають у ролі основи усіх онтологічних процесів, які відбуваються у навколишньому середовищі. При цьому процесами поєднання та диференціації вказаних чотирьох стихій безпосередньо управляють дві космічні сили - любов та хаос, які перебувають у стані постійного протистояння між собою. У випадку, коли переважає любов - усе постає у стані синтезу, є позитивно-правильним завдяки чому і стає можливим процес народження. Aле такий стан не є сталим, а тим більше вічним, адже 3 космосу починає свій наступ хаос, який у результаті призводить до повної диференціації вихідних елементів, результатом чого, природно, є загибель та знищення [5, с.8].

Емпедокл не виявляв повної згоди із ученнями елеатів стосовно проблематики пізнання. Він вважав, що даний процес дійсно повинен грунтуватися на раціональних основах, але на відміну від елеатів, допускав існування позитивного впливу почуттів на розум індивіда.

Щодо політико-правових уявлень Емпедокла, то на даний час відомим є лише те, що мислитель приймав активну участь в політичному житті соціуму й навіть був очільником демократичної партії в його рідному місті Акраганта (Сицилія). Він активно виступав за збереження демократичного ладу в місті при вчиненні спроби реставрації аристократичного устрою на теренах полісу.

Водночас інший представник Іонійської школи - Анаксагор, став відомим завдяки тому, що намагався узгодити погляди представників іонійської натурфілософії та елеатів, а саме - поєднати матеріальне із раціональним. Анаксагора у науковому світі не прийнято вважати мислителем, так би мовити, «перших рядів», але слід зазначити, що саме він поширив на теренах Афін такий аксіологічний феномен, як філософія. Також у науковому світі існує думка, що саме його світоглядні ідеї вчинили досить значний вплив на процес формування філософського світогляду в Сократа [8].

Наступним серед представників Іонійської школи натурфілософії слід назвати вчителя Сократа - Архелая, який у парадигмі власних філософських ідей надавав значної ваги саме повітрю та безкінечному, вважаючи їх основними чинниками існування всього сущого, в тому числі й такої сутності, як душа, яка формується, на думку Архелая, саме із повітря. Зі змісту наведеної тези стає зрозумілим, що Архелай виступав у ролі прихильника матеріалістичної концепції природи душі. У його поглядах можна прослідкувати існування власної натурфілософської концепції створення світу, яка полягала в протистоянні холодного й гарячого (води й вогню), яких, у свою чергу, примирив матеріальний Нус, створивши світ, у якості нижчої форми існування. Люди, на думку мислителя, також походять із нижчих форм існування, які спочатку були на рівні з тваринами, але згодом почали об'єднуватися в племена зі своїми законами, що власне й допомогло їм виділитися серед інших живих істот. Архелая вважають останнім натуралістичним філософом, після якого його учень Сократ здійснив кардинальний «переворот» у сфері філософії спрямувавши вектор іiі пізнання на саму людину, на іiі внутрішній світ.

Доцільним також, на наш погляд, буде згадати й ще одного представника вказаної філософської школи, а саме - Діогена Аполонійського, який за першооснову всього сущого визначав повітря у різних притаманних йому станах (ступенях ущільнення). За вченням Діогена, земля - це охолоджене повітря, а, приміром, душа - це тепле повітря. Аюдське пізнання також формується за допомогою повітря, яке проходячи через кров виступає у ролі каталізатора синтезу думок, які зароджуються в серці індивіда.

На жаль, так би мовити, «безпосередніх» поглядів іонійців стосовно походження і природи права нам віднайти не вдалося, але зміст притаманних їм світоглядних ідей несе у собі неабияке значення для формування відомих нині у науковому світі політико-правових доктрин.

Досократичний період давньогрецької філософії також неможливо уявити і без сві- 


\section{Філософія та психологія права}

тоглядних ідей сформульованих мислителями-атомістами. Більшою мірою це стосується таких мислителів, як Аевкіпп та Демокрит.

За світоглядними уявленнями Аевкіппа, - світ, у цілому, складається із атомів та порожнечі, у якій ці атоми, будучи неподільними, беззмінними та безякісними, відрізняючись лишень між собою величиною та формою, перебувають у постійному русі й пересуваючись по порожнечі утворюють вихори, а з них - і світи. Запропоновану Аевкіппом атомістичну теорію походження всього сущого розвинув інший давньогрецький філософ Демокрит, який вперше розглянув проблематику становлення соціуму, у якості частини світового еволюційного поступу. Поліс та законодавство у ньому, на переконання філософа, мають штучне походження, у даному факторі й криється притаманна їм недосконалість. Мислитель навіть не припускав існування факту надприроднього походження закону та був глибоко переконаним, що він повинен відповідати природі. «Те, що вважається справедливим - не є справедливе: несправедливим ж є те, що протирічить природі»- говорив Демокрит [9, с.159].

Мислитель був яскравим прихильником демократичного устрою держави, стверджуючи, що «бідність за демократії є кращою аніж багатство при царях, настільки, наскільки свобода є кращою аніж рабство» [7, с.319]. На думку філософа держава $\epsilon$ «загальною справою» їі громадян і служить для них у якості опори. Коли держава є благополучною, - вказував Демокрит, - усі перебувають у стані благополуччя, коли вона гине - гине все [6, с.361]. У свою чергу закони покликані забезпечити належне життя громадян у полісі, при цьому Демокрит їх не возвеличував й не надавав їм божественного наповнення, вважаючи їх написаними людьми, а відтак такими, які можна за необхідності піддавати змінам. Закон, на думку філософа, поступається цінністю перед чеснотами, але може виступати способом для залучення простих громадян до чеснот й водночас каральним інструментом для приборкання в них заздрості, розбрату й тяги до заподіяння шкоди іншому. Мудрецям, вважав Демокрит, закони не потрібні й вони не повинні їм коритися, адже немає жодної потреби в моральній опіці держави та їі законів над мудрецями, оскільки вони живуть чесним та вільним життям.

Наразі такі погляди Демокрита комусь можуть видатися недосконалими та суперечливими. Можна також сформулювати думку з приводу недопустимості вибіркового правосуддя в умовах сьогодення, адже це фактично суперечить сучасним юридико-науковим доктринам та правовим традиціям. На нашу думку також слід погодитися із тим, що з теоретичної точки зору в третьому тисячолітті неприпустимою $є$ навіть думка про вибіркове правосуддя, але приглянувшись більш детально до існуючих реалій сьогодення, можна виявити існування досить сумного факту 3 приводу того, що така нерівність існує й на сьогодні, щоправда у різних завуальованих проявах.

\section{Висновки}

Проведений нами короткий аналіз філософсько-правових поглядів давньогрецьких філософів досократичного періоду дає нам підстави стверджувати, що такі мислителі як Платон та Арістотель сформували цілісні, сталі та логічно обгрунтовані власні філософсько-світоглядні системи, залишили по собі творчий спадок, у змісті якого виклали власне бачення тієї чи іншої світоглядної проблематики, у тому числі не залишили поза власною увагою такі філософсько-світоглядні категорії, як держава і право, із якими, принагідно зазначимо, вчення створені зусиллями досократиків навряд чи здатні повноцінно конкурувати ані за обсягами ані за притаманним їм змістом. Та усе ж, на наш погляд саме досократики визначили певний вектор наступного розвитку філософії та саме належні їм праці виступили у якості джерельної бази, каталізатора для подальших наукових розвідок таких мислителів, як Платон, Арістотель та інші філософи. Саме досократики заклали аксіологічні основи тієї сфери суспільного буття, яке ми зараз називаємо філософією та філософією права зокрема.

\section{Мiтература}

1. Анаксимен. Философский энциклопедический словар / Л.Ф.Ільчев, П.Н.Федосеев, С.М.Ковалев, В.Г.Панов. М: Советская энциклопедия, 1983. 840 с. 
2. Гатри У. К. Ч. История греческой философии в 6 т. Т. I: Ранние досократики и пифагорейцы / У. К. Ч. Гатри / Пер. с англ. под ред. и с прим. А. Я. Жмудя. СПб.: «Владимир Даль», 2015. 863 с.

3. Геракліт.

Філософський енциклопедичний словник / B.I. Шинкарук (голова редколегії). - К: Абрис, 2002. 742 с.

4. Гоббс Т. Сочинения: в 2-х т. [пер. с лат. и англ.] / Т. Гоббс [сост., ред. и примеч. В.В. Соколова]; АН СССР, Институт философии. Москва: Мысль, 1989-1991. Т. 2. 1991.735 с.

5. Іонійська натурфілософія. Навчальнометодичний посібник / М.Марчук, С.Мудра, Т.Радзиняк. Чернівці: Чернівецький національний університет ім. Ю. Федьковича, 2015. $255 \mathrm{c}$.

6. Аурье С.Я. Демокрит / С.Я.Аурье. М., 1970.664 c.

7. Маковельский А.О. Древнегреческие атомисты / А.О.Маковельский. Баку, 1946. 402 c.

8. Мануссакіс Д-П. Рух мислення: від Анаксагора до Максима Сповідника / Д-П. Мануссакіс. URL: https://www.verbum.com. ua/08/2019/meaning-of-transience/thinking$\underline{\text { moves }}$

9. Материалисты Древней Греции. М.: Политиздат, 1955. 217 с.

10. Меленко С. Г. Давньогрецькі витоки української філософсько-правової думки : монографія / С. Г. Меленко. Чернівці : Технодрук, 2013. 432 с.

11. Меленко С.Г. Проекція філософськоприродничих уявлень Анаксімандра Мілетського на проблеми процесу державотворення / С.Г.Меленко. Чернівці: Науковий вісник Чернівецького університету. Випуск 599. Правознавство, 2011. С. 18-22.

12. Меленко С.Г. Число як першооснова філософських та правових поглядів Піфагора Самоського / С.Г.Меленко // Науковий вісник Чернівецького університету: 3б. наук. Праць. Випуск 604: Правознавство. Чернівці: Чернівецький нац. ун-т, 2011. С.25-28.

13. Політологія: Навчально-методичний комплекс. Поняття про демократію. Витоки, зміст та основні їі форми / Ф.М.Кирилюк, А.Є.Конверський, В.Ф.Білик. К: Київський національний університет імені Тараса Шевченка. 2004.

14. Узбек К.М. Фрагменти побудови античної науки, філософії i культури / К.М.Узбек. Донецьк: Східний видавничий дім, 2010. 234 c.

15. Шульженко Ф.П., Андрусяк Т.Г. Історія політичних і правових вчень / Ф.П.Шульженко, Т.Г.Андрусяк. К: Юрінком Інтер, 1999. 304 с.

\section{IDEOLOGICAL ORIGINS AND ONTOLOGICAL PECULIARITIES OF THE ANCIENT GEEK PHILOSOPHY OF LAW OF THE PRE-SOCRATIC PERIOD}

Based on the ontological and epistemological analyses, the article under studies deals with the significance of the Ancient Greek Philosophy of Law of the pre-Socratic period and its impact on the formation and development of certain fundamental present-day legal notions. The author of the article reveals the basic ontological views of the pre-Socratic Ancient Greek philosophers on the perception of the surrounding reality. He points out the variability of thinkers' attitude to such socially important categories as the state, the law, the management system, etc. The article lays particular emphasis on the fact that the pre-Socratic philosophers were willing to determine the root cause of everything that existed in the Universe. In this desire, they paid peculiar attention to different subjects and phenomena, which were comprehensive for human understanding, at the same time, being located beyond the human "self". In other words, their search for the root cause was reduced to the plane that was beyond the very essence of the individual. In this case, the person acted exclusively as a subject of scientific search, whereas the vector of knowledge was directed from the social individual to the outside.

Trying to explain the root cause of existence, as well as the interconnection between the objects of being, the pre-Socratic philosophers could not ignore such social phenomena as the state, the law and the system of management, since only due to them it is possible to make up a certain mechanism of social regulation. Even though each representative of the pre-Socratic period had his own idea of such a mechanism, they eventually came to the common conclusion that the above phenomena should be based on natural laws, which would ensure the balance in the relationship between the individual social units. Therefore, the scientific heritage of the pre-Socratic Philosophy is rather interesting and requires a thorough analytical investigation in order to apply its scholastic principles in the present-day reality. It is essential because the issue of defining the phenomena of law, state and he system of management remains relevant today. Consequently, the retrospective analysis of their evolution will provide the opportunity for carrying out profound research in this field with the aim of solving today's problems.

Key word: Ancient Greek Philosophy, preSocratic period, original item, law, state, the system of management. 